\title{
SPECIATION OF HEAVY METALS IN THE SOIL AND THE MINING RESIDUES, IN THE ZINC- LEAD SIDI BOU OTHMANE ABANDONED MINE IN MARRAKECH AREA
}

\author{
Mouhsine Esshaimi \\ Naaila Ouazzani \\ Abdelhay El Gharmali \\ Fatima Berkhis \\ Manuel Valiente \\ Laila Mandi \\ University of Caddi Ayyad, Morocco \\ National Center for Studies and Research on Water and Energy, Morocco \\ University Autonoma de Barcelona, Spain
}

\begin{abstract}
Mining activity is one of the most important sources of Heavy metals in the environment. In Marrakech region, functioning or abandoned mines represent a great hazard due to huge amounts of waste deposited in waste dumps and tailings often with high concentration of heavy metals pollution. These mining sites located near Marrakesh contain mining residues abandoned for ten to twenty years. They are presently in an agricultural region of the Haouz district (Jbilets- Centrales). The present study was realized for the abandoned mine of Sidi Bou Othmane in order: i) -To determine the total content of heavy metal in soil and mining residues, ii)-To carry out the chemical speciation, of heavy metals in the mining residues and in the samples of soil collected in the vicinity of the mine.

The $\mathrm{pH}$, the electrical conductivity, Organic matter content and Total carbonate content in all the samples (soil and mining residues) were measured using the standards methods, heavy metals concentration was determined by atomic spectrophotometery. Therefore, a sequential extraction scheme according to the BCR's (Community Bureau of Reference) guidelines and total acid digestion were applied to soil and mining residues samples. The results obtained showed that all the abandoned mines still containing very important quantities of solid waste, these sites can thus become potential sources of pollution by releasing heavy metals. In this concern, 4 polluting heavy metals $(\mathrm{Cd}, \mathrm{Cu}, \mathrm{Pb}$ and $\mathrm{Zn})$ were detected with concentrations exceeding those admitted for agricultural soil. For all heavy metals, the most contaminated sites were found in the vicinity of the mines, probably linked to weathering effect, the wind and the topography.
\end{abstract}

\section{KEYWORDS}

Soil; mining residues; heavy metals; sequential extraction.

https://doi.org/10.15626/Eco-Tech.2010.102 
Linnaeus ECO-TECH '10

Kalmar, Sweden, November 22-24, 2010

\section{INTRODUCTION}

Mining and milling operations, together with grinding, concentrating ores and disposal of tailings, provide obvious sources of contamination in the surface environment, along with mine and mill waste water [1].As a result, elevated levels of heavy metals can be found in and around disused metalliferous mines due to discharge and dispersion of mine wastes into nearby agricultural soils, food crops and stream systems. Eventually, they may pose a potential health risk to residents in the vicinity of mining areas.

Southern Morocco has a large number of metalliferous Sites (Chronicle of Mineral Research and Exploration, 1998) and has been considered as a traditional mining region since antiquity. Nowadays, it is estimated that there are still large reserves of iron $(\mathrm{Fe})$, copper $(\mathrm{Cu})$, zinc $(\mathrm{Zn})$, silver $(\mathrm{Ag})$ and lead $(\mathrm{Pb})$ in the area. Both active and abandoned mines present a risk of contamination of soils, plants, groundwater and surface water by dissemination of the particles carrying metals by wind action and/or by runoff from the tailings. .High mining activity can be found in Marrakech region where functioning or abandoned mines represent a great hazard due to huge the presence of high amounts of heavy metals. In this concern, few studies have been done in this area to determine the concentration of heavy metals in the mining residues and their impact on surrounding soil and water resources.

The total metal concentration obtained after a strong acid digestion does not provide sufficient information of its potential hazardous effects on environment because the mobility and ecotoxicity of heavy metals depend strongly on their specific chemical forms or binding. Consequently, these are the parameters that have to be determined, rather than the total element contents, in order to assess toxic effects. If heavy metals exist as loosely bound fractions such as soluble, exchangeable and adsorbed forms, they tend to be easily moved and dispersed. However, metals asscoiated with organic ligands or in crystal lattices are not easily separated or mobilized. To determine the speciations of heavy metals, various methods have been developed over the last two decades involving both single and sequential extraction schemes [2]. Although some methods have been widely used, none has been unreservedly accepted by the scientific community. For this reason the Community Bureau of Reference (BCR) in 1987 began a programme to harmonise the methodology in the sequential extraction schemes used for determining metals in a variety of matrices, including lake, lagoon and marine sediments, sewage sludge, soil and industrially contaminated made-up ground [3]. The aim of this study was to determine total heavy metals contents and their chemical fractions in the mining residues and in the samples of soil collected in the vicinity of $\mathrm{The} \mathrm{Pb}-\mathrm{Zn}$ abandoned mine of Sidi Bou Othmane.

\section{MATERIALS AND METHODS}

\subsection{Description of the site investigated}

The abandoned Sidi Bou Othmane mine is localized at $30 \mathrm{~km}$ in the north of Marrakech, in the region of the Haouz district (Jbilets- Centrales) in southern Morocco (figure 1) and it consists of Palaeozoic terrains. The climate is Mediterranean, bordering arid and semi arid with an average annual precipitation of $231 \mathrm{~mm}$ (10 years). Temperatures are characterized by great daily and seasonal variation with an average value of $11.5 \mathrm{C}$ in January and $28.8 \mathrm{C}$ in July. The mining site Sidi-Bou Othmane is about a rural district, surrounded by vast fields of arable grounds .the first work in the mine Sidi-Bou Othmane go back to the year 1953. In 1961 a company CRAM built a treatment plant of the product crusher-run aggregate with a laundry. The extraction continued until the year 1980. The laundry was designed for a capacity of 115 tons per day $(0,5 \% \mathrm{~Pb}, 7,4 \% \mathrm{Zn}$ and $6 \%$ pyrite) using flotation processes. 


\subsection{Sampling description}

The location of the sampling points is shown in figure 2. In order to assess the impact of the abandoned mine residues on the surrounding soils, a total of 9 samples of soils were collected in the vicinity of the mine (One sample was obtained by mixing 10 elementary samples collected on the sector) and 3 representative background samples at $1 \mathrm{~km}$ from the mining site in order to avoid mining contamination. Samples were taken from the upper $20 \mathrm{~cm}$ after removing the first layer of surface soil $(2 \mathrm{~cm})$.

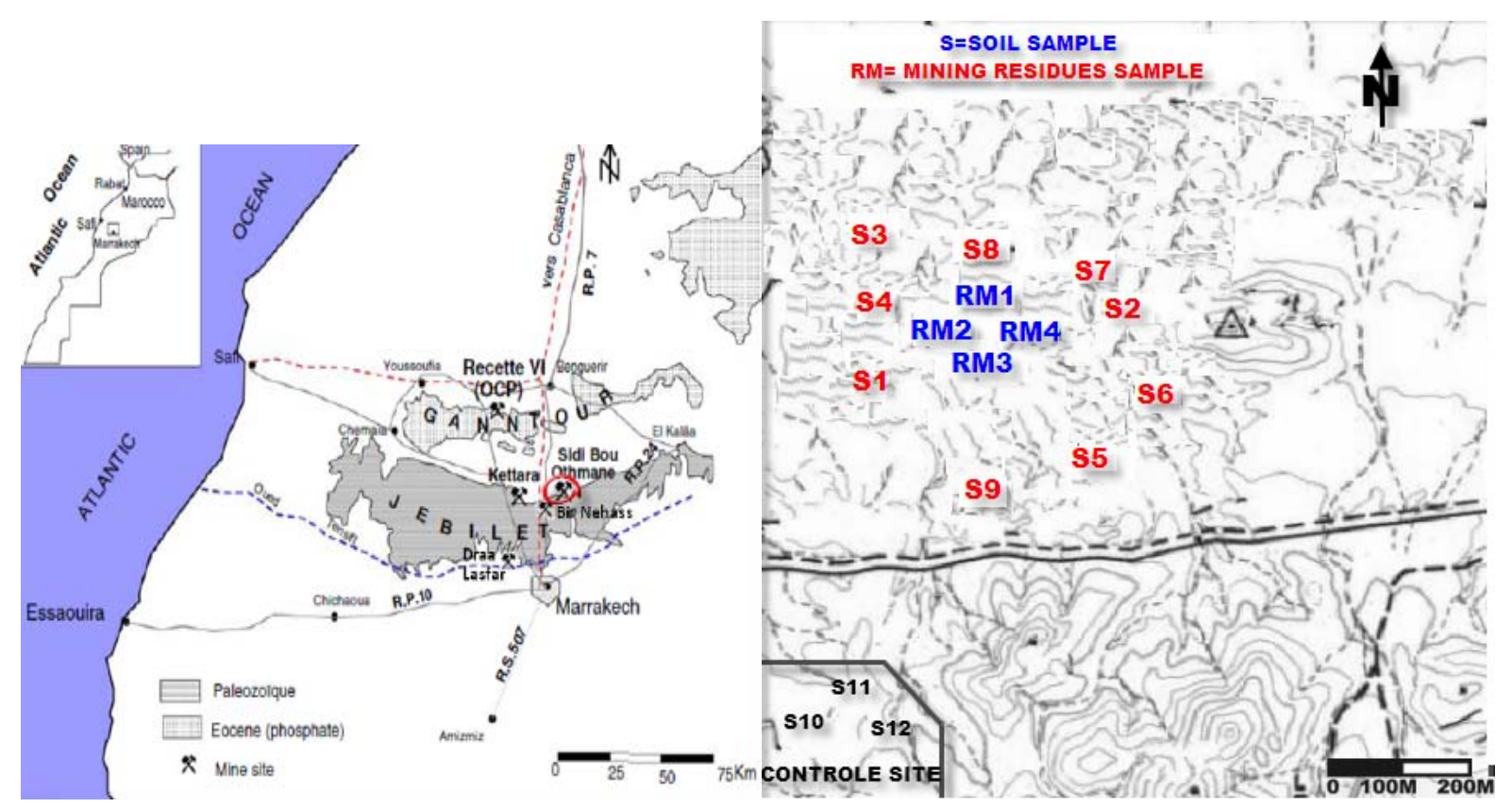

Figure 1. Location of Sidi Bou Othmane mine. Figure 2. Sampling locations of soils and the

mining residues in the vicinity of

the abandoned Sidi Bou Othmane mine.

The sampling of the mining residues was carried out in the discharge of mining site, the discharges of these waste lands are in the form of juxtaposed hills of residues. For this reason the taking away were carried out in several points in order to have an average sample. The average sample of each discharge is considered after mixture of the various sub-samples. The samples (soil and mining residues) were placed in labeled Polyethylene bags for transport to the laboratory. Next, the samples were air-dried at ambient temperature for 48 hours, disaggregated and sieved to an adequate size for further analysis $(<2 \mathrm{~mm}$ or $<100 \mu \mathrm{m})$. Due to the strong association and affinity of heavy metals with fine grained soil components, we used the $<100 \mu \mathrm{m}$ soil fraction for the sequential extraction and total acid digestion methods $[4,5$, 6]. The $<2 \mathrm{~mm}$ soil fraction was used to determine the $\mathrm{pH}$, electrical conductivity (EC), Organic matter content $(\mathrm{OM})$ and carbonate.

\subsection{Sample analysis}


The physical-Chemical characterization consisted in the determination of the soil and mining residues $\mathrm{pH}$, Electrical conductivity (EC), Organic matter content (OM) and the carbonate content of the samples according to standard methods [7]. The $\mathrm{pH}$ was measured in a soil and mining residues suspension $(2 \mathrm{~g} / 5 \mathrm{ml}$ of distilled water stirred vigorously) after $2 \mathrm{~h}$ of deposition using a pH-meter (Model WTW Multiline P4 Universal pH-meter cabled Sen-Tix $92 \mathrm{~T} \mathrm{pH}$ electrode, Germany). EC was determined in a soil and mining residues saturated paste $(1 \mathrm{~g} / 5 \mathrm{ml}$ of distilled water) with a conductimeter (Model WTW Multiline P4 Universal Standard Conductivity Cell TetraCon ${ }^{\circledR} 325$, Germany), once corrected to the working temperature $\left(20^{\circ} \mathrm{C}\right)$. For the total carbonate content three replicates of each soil were stirred during $6 \mathrm{~h}$ in an $\mathrm{HCl} 4 \mathrm{~N}$ solution (1g of soil per $20 \mathrm{ml}$ of $\mathrm{HCl} 4 \mathrm{~N}$ solution) and, after filtering, calcium was measured by flame spectroscopy (Model JENWAY-PFP7).

Total heavy metal concentration was determined by AAS after digestion of the samples. 0,50 $\mathrm{g}$ dry sample was weighted in a Teflon beaker and $7 \mathrm{~mL} \mathrm{HNO} 3(65 \% \mathrm{w} / \mathrm{w}), 2 \mathrm{~mL}$ HF $(40 \%$ $\mathrm{w} / \mathrm{w})$ and $1 \mathrm{~mL} \mathrm{HCIO} 4(60 \% \mathrm{w} / \mathrm{w})$ were added. The Teflon beaker was placed on a hotplate until total digestion. After digestion, the sample solution was allowed to air-cool and then diluted with deionized water to $50 \mathrm{~mL}$. The optimized BCR sequential extraction procedure was applied to assess heavy metal fractionation in the samples $(<100 \mu \mathrm{m}$ fraction). This method was described in detail elsewhere [10].The sequential extraction was performed using the three-step procedure recommended by BCR. Additionally, a fourth step was added, which consisted of dissolving the final residue using the same digestion procedure for the total metal determination. The method details are presented in Table 1.

Table 1. Modified BCR three-step sequential extraction procedure [8].

\begin{tabular}{|c|c|c|c|}
\hline Step & Fraction & Target phases & Modified BCR \\
\hline 1 & $\begin{array}{c}\text { Exchangeable, } \\
\text { water and acid } \\
\text { soluble }\end{array}$ & $\begin{array}{l}\text { Soluble species, } \\
\text { carbonates, cation } \\
\text { Exchange sites }\end{array}$ & $0.11 \mathrm{~mol} / 1$ acetic acid \\
\hline 2 & Reducible & $\begin{array}{l}\text { Iron and manganese } \\
\text { oxyhydroxides }\end{array}$ & $\begin{array}{c}0.5 \mathrm{~mol} / 1 \text { hydroxyl ammonium } \\
\text { Chloride at } \mathrm{pH} 1.5\end{array}$ \\
\hline 3 & Oxidisable & $\begin{array}{l}\text { Organic matter and } \\
\text { sulphides }\end{array}$ & $\begin{array}{l}\text { Hydrogen peroxide followed } \\
\text { By } 1 \mathrm{~mol} / 1 \text { ammonium } \\
\text { Acetate at } \mathrm{pH} 2\end{array}$ \\
\hline 4 & Residual & & $\begin{array}{c}7 \mathrm{~mL} \mathrm{HNO}_{3}+2 \mathrm{~mL} \mathrm{HF}+1 \mathrm{~mL} \\
\mathrm{HCIO}_{4}\end{array}$ \\
\hline
\end{tabular}

\section{RESULTS AND DISCUSSION}

\section{1. physical-Chemical properties of soils and mining residues}

Some chemical characteristics of mining residues and soils in the vicinity of the zinc-lead abandoned mine of Sidi Bou Othmane are presented in Table 2. The results obtained for the soil $\mathrm{pH}$ measurements, revealed that, in general, all samples of mining residues and soil presented a neutral to alkaline $\mathrm{pH}$ ranging from 7,30 to 8,12 , similar to background samples. $\mathrm{PH}$ variations seemed to be related to heterogeneous deposits of residues in the surroundings of the mine which can cause a decrease on the $\mathrm{pH}$, neutral and alkaline $\mathrm{pHs}$ in soil and mining 
residues could be attributed to the presence of carbonates with a high concentration ranging from 122,35 to $131,09 \mathrm{mg} . \mathrm{g}^{-1}$ for mining residues; and from 23,72 to $462,00 \mathrm{mg} . \mathrm{g}-1$ for soil , high values of carbonates in mining residues may be due primarily to the mixture of these mining residues with soil very rich in carbonates .

The EC measurements, revealed that, all samples of mining residues presented a high values ranging from 2140,00 to $2270,00 \mu \mathrm{s} / \mathrm{cm}$, for soil EC showed more variability than the $\mathrm{pH}$, with EC values ranging from 134,6to $600,00 \mu \mathrm{s} / \mathrm{cm}$. In general, these results are correlated with previous studies carried on Morocco soils [9]. A decreasing salinity gradient was also observed and the values obtained for the soil samples are significantly higher than for the background samples. The highest values are observed for samples S8, S4, and S1, located nearly of the mining residues deposits. All the soil samples presented a very high Organic matter content ranging from 6,24 to $7,81 \%$, similar to background samples, these values are due to the nature of soil (Arable land and cultivated soils ). The presence of a vegetation cover in some parts of the mining area, and the mixture of the mining residues with a soil, could explain the high values of OM content in samples corresponding to the mining residues (4,28 to $4,71 \%)$. Together with basic $\mathrm{pH}$ values, the presence of carbonates in the soil lead to an increase in the retention of heavy metals, mainly as carbonate salts as a consequence of the ionic exchange, the principal retention mechanism of heavy metals [10].

Table 2. pH, Electrical conductivity (CE), Organic matter content (OM) and CaCO3 content in soil and mining residues in the vicinity of the abandoned Sidi Bou Othmane mine area.

\begin{tabular}{cccccc}
\hline & Sample & $\mathbf{p H}$ & $\begin{array}{c}\mathbf{C E} \\
(\boldsymbol{\mu s} / \mathbf{c m})\end{array}$ & $\begin{array}{c}\mathbf{C a C O 3} \\
(\mathbf{m g} / \mathbf{g})\end{array}$ & $\begin{array}{c}\mathbf{O M} \\
\mathbf{\%}\end{array}$ \\
\hline \multirow{3}{*}{$\begin{array}{c}\text { Mining Residues } \\
\text { samples }\end{array}$} & RM1 & 7,47 & 2270,00 & 124,85 & 4,62 \\
& RM2 & 7,30 & 2570,00 & 122,35 & 4,54 \\
& RM3 & 7,42 & 2140,00 & 122,47 & 4,28 \\
& RM4 & 7,40 & 2310,00 & 131,09 & 4,71 \\
& & & & & \\
& S1 & 7,64 & 454,29 & 30,00 & 6,33 \\
Soil Samples & S2 & 7,65 & 251,25 & 62,43 & 6,82 \\
& S3 & 8,04 & 113,46 & 300,5 & 6,96 \\
& S4 & 7,81 & 429,47 & 70,10 & 7,56 \\
& S5 & 7,90 & 227,62 & 94,9 & 6,24 \\
& S6 & 7,89 & 134,60 & 23,72 & 6,35 \\
& S7 & 7,54 & 330,19 & 37,45 & 6,50 \\
Soil Background & S8 & 7,50 & 600,00 & 284,54 & 7,81 \\
Samples & S9 & 8,12 & 136,84 & 462,00 & 7,79 \\
& & & & & \\
& BS & 8,00 & 100,4 & 99,88 & 6,90 \\
\hline
\end{tabular}

\subsection{Total Heavy Metal Levels in soils and mining residues}

Total metal concentrations were classified based on the background levels for sandy soils [11], and the upper values established by European Directive 86/278/EEC [12]. Values of 
total $\mathrm{Pb}, \mathrm{Zn}, \mathrm{Cd}$ and $\mathrm{Cu}$ concentrations in the samples of soil and mining residues (determined after acid digestion), are shown in Table 3.

As expected, in most of the mines, the mining residues had higher metal concentrations than soils, the Mining residues from this abandoned mine contained very high levels of $\mathrm{Zn}(18,06-$ 42,51 g. $\left.\mathrm{kg}^{-}{ }^{1}\right), \mathrm{Pb}\left(9,24-20,63 \mathrm{~g} \cdot \mathrm{kg}^{-}{ }^{1}\right), \mathrm{Cu}\left(117,60-127,60 \mathrm{mg} \cdot \mathrm{kg}^{-1}\right)$ and $\mathrm{Cd}(45,14-105,30 \mathrm{mg}$ . $\left.\mathrm{kg}^{-}{ }^{1}\right)$. The adjacent soils were also highly contaminated with metals $(\mathrm{Zn}>\mathrm{Pb}>\mathrm{Cu}>\mathrm{Cd})$, according the classification of the upper values established by European Directive 86/278/EEC [12] , more than two-thirds of the samples of soil were highly polluted with Zn, while nearly half of the samples showed levels of $\mathrm{Zn}$ and $\mathrm{Cd}$ considered to be not tolerable. $\mathrm{Cu}$ concentrations were mainly low, the majority of the samples showing values considered as background or tolerable levels.

The soils taken near the area covered by mining residues showed the highest values for all the metals (S8, S4, S7 and S2). Indeed, almost all theses samples were classified into very polluted levels [12].for $\mathrm{Zn}, \mathrm{Pb}$, and $\mathrm{Cd}$ (values particularly high for zinc and lead). S1 S3 and S6 were also classified into very polluted levels particularly for Zinc, the rest of the samples (S5 and S9) were considered as background or tolerable levels [11].

Table 3. Total heavy metal content of soil and mining residues in the vicinity of the abandoned Sidi Bou Othmane mine.

\begin{tabular}{cccccc}
\hline & Sample & $\begin{array}{c}\mathbf{Z n} \\
(\mathbf{m g} / \mathbf{k g})\end{array}$ & $\begin{array}{c}\mathbf{P b} \\
(\mathbf{m g} / \mathbf{k g})\end{array}$ & $\begin{array}{c}\mathbf{C u} \\
(\mathbf{m g} / \mathbf{k g})\end{array}$ & $\begin{array}{c}\mathbf{C d} \\
(\mathbf{m g} / \mathbf{k g})\end{array}$ \\
\hline \multirow{2}{*}{$\begin{array}{c}\text { Mining Residues } \\
\text { samples }\end{array}$} & RM1 & 42514,28 & 9240,00 & 124,57 & 67,67 \\
& RM2 & 37405,71 & 16811,43 & 123,43 & 105,30 \\
& RM3 & 18045,71 & 9250,00 & 127,60 & 45,14 \\
& RM4 & 21531,43 & 20628,57 & 117,60 & 69,40 \\
\multicolumn{1}{c}{ Soil Samples } & S1 & 921,00 & 282,00 & 46,50 & 2,89 \\
& S2 & 2604,00 & 816,00 & 72,00 & 6,23 \\
& S3 & 545,00 & 154,00 & 12,00 & 0,00 \\
& S4 & 13555,00 & 3723,00 & 61,50 & 13,00 \\
& S5 & 233,00 & 74,00 & 57,00 & 0,00 \\
& S6 & 333,00 & 97,00 & 66,00 & 0,00 \\
Soil Background & S7 & 2154,00 & 1702,00 & 70,50 & 4,10 \\
Samples & S8 & 12827,00 & 4634,00 & 55,50 & 12,70 \\
& S9 & 276,00 & 125,00 & 58,50 & 0,00 \\
& & & & & \\
& BS & 107,55 & 30,00 & 12,00 & 0,00
\end{tabular}

All the heavy metals values determined were above the maximum values allowed in the directives [12], it is very important to consider that these elements (particularly zinc and lead) has high toxicity, this fact suggests the common origin of all the metals analyzed and, 
therefore, the mining activity can be pointed out as the source for the metal pollution of the studied area: Two reasons may be suggested to explain the scattering of the metals from the mine area. Firstly, the mining residues had higher metal concentrations (Table 3), particularly $\mathrm{Zn}$ and Lead, this fact is probably due to the post processing of the mine tailings, which were crushed, grinded and treated by flotation. This process would have recovered the small amounts of ore minerals (e.g. galena $(\mathrm{PbS})$, sphalerite $(\mathrm{ZnS})$ remaining in the tailings from the original works, (The laundry was designed for a capacity of 115 tons per day $(7,4 \% \mathrm{Zn} 0,5 \%$ $\mathrm{Pb}$, and $6 \%$ pyrite) using flotation processes ). Secondly, wind transport of dust may be another important factor influencing the spreading of pollution.

\subsection{Speciation of Heavy Metal in soils and mining residues}

Measurement of total concentration of metals in soils is useful to detect any net change due to different possible phenomena such as erosion and leaching to groundwater, but does not give any indication about the chemical form of metals in soils. Because of the dependence of metal mobility on the interaction of metal with soil, several sequential leaching procedures have been developed to selectively remove metals from the different geochemical forms. Due to the high $\mathrm{Pb}$ and $\mathrm{Zn}$ levels in the samples analyzed and the nature of the Sidi Bou Othmane mine, $\mathrm{Pb}$ and $\mathrm{Zn}$ were selected for studying their geochemical distribution in the soil samples and in mining residues samples.

The concentration of exchangeable, reducible, oxidizable and residual metals obtained after the application of the sequential extraction recommended by the BCR and the recovery rate were represented in Tables 4 -5.The sum of extractable fraction of metals is reasonably similar to total contents obtained after total acid digestion. The recovery rate was 90,96$105,66 \%$ for $\mathrm{Pb}$ and $91,85-106,19 \%$ for $\mathrm{Zn}$.

The first fraction from the BCR extraction procedure Exchangeable (F1) includes weakly absorbed metals retained on the soil surface (such as clay minerals, organic matter and hydrous oxides) by relatively weak electrostatic interaction, metals that can be released by ionexchange processes and metals that can be precipitated or coprecipitated with the carbonates present in many soils. This fraction is considered to be the most bioavailable of the different metal forms and it is also the most labile .

The highest values of exchangeable fraction (Step 1) were observed for $\mathrm{Pb}$ and $\mathrm{Zn}$, especially for mining residues, the values were ranged from 35,29 to $37,48 \%$ of the total metal of $\mathrm{Pb}$ and from 52,94 to $59,37 \%$ of the total metal of $\mathrm{Zn}$. Taking into consideration the high mobility and potential bioavailability of heavy metals in this fraction and their total concentration (Table 3 ) it can be concluded that these wastes could have potentially hazardous effects on the environment.

The F1 concentrations for soils samples (S8, S4, S7, S2 and S6) taken near the area were ranged from 51,35 to $87,57 \%$ of the total metal of $\mathrm{Zn}$ and from 30,75 to $64,35 \%$ of the total metal of $\mathrm{Pb}$, the Other samples ( S1, S3, S5, and S9) located at distances further away from the mining residues present the following results : The $\mathrm{F} 1$ concentrations were ranged from 10,75 to $47,90 \%$ for $\mathrm{Zn}$ and from 6,18 to $26,19 \%$ for $\mathrm{Pb}$. For this fraction (F1), it can be seen that $\mathrm{Zn}$ concentrations were significantly higher than $\mathrm{Pb}$ concentrations in the majority of the soil samples. Several authors have reported the relatively high mobility of $\mathrm{Zn}$ in the soil environment, which makes it considerably more mobile than lead [13]. Zinc is readily adsorbed by clay minerals, carbonates, or hydrous oxides and is in the exchangeable form [14]. 
In the majority of samples collected, large amounts of $\mathrm{Pb}$ were mainly associated with the reducible form (F2), The concentrations (F2) represent high percentages of the total metal content between 57,51-61,05\%, and 23,23- 83,05\% for mining residues and soil respectively.. Zn content in F2 ranged from (34,63-42,39\%), for mining residues and $(0,00$ $45,70 \%$ ), for soil. Although the percentages of $\mathrm{Pb}$ associated with $\mathrm{F} 2$ were higher than those of $\mathrm{Zn}$, high concentrations of $\mathrm{Zn}$ were found in mining residues. The incoming pollutants from external polluting sources initially exist in unstable chemical forms and continued pollutant accumulation leads to the formation of precipitates, especially as reducible forms [15].

Table 4. Fractionation of $\mathrm{Zn}$ by BCR sequential extraction (concentration in $\mathrm{mg} \mathrm{kg}^{-}$) for soil and mining residues in the vicinity of the abandoned Sidi Bou Othmane mine.

\begin{tabular}{cccccccc}
\hline & $\begin{array}{c}\text { Exchangeable } \\
(\mathbf{F 1})\end{array}$ & $\begin{array}{c}\text { Reducible } \\
(\mathbf{F 2})\end{array}$ & $\begin{array}{c}\text { Oxidizable } \\
\mathbf{( F 3 )}\end{array}$ & $\begin{array}{c}\text { Residual } \\
\mathbf{( F 4 )}\end{array}$ & Sum & $\begin{array}{c}\text { Total } \\
\text { concentration }\end{array}$ & $\begin{array}{c}\text { Recovere } \\
\mathbf{d} \%\end{array}$ \\
\hline RM & & 16068,0 & & & 39752,6 & & \\
$\mathbf{1}$ & 21248,00 & 0 & 1895,00 & 541,60 & 0 & 42514,28 & 93,50 \\
RM & & 15632,0 & & & 36881,1 & & \\
$\mathbf{2}$ & 19524,80 & 7 & 1335,12 & 389,12 & 1 & 37405,71 & 98,60 \\
RM & & & & & 18905,4 & & \\
3 & 10032,21 & 7758,23 & 913,65 & 201,32 & 1 & 18045,71 & 104,76 \\
RM & & & & & 20573,1 & & \\
4 & 12214,61 & 7123,76 & 956,45 & 278,32 & 4 & 21531,43 & 95,55 \\
& & & & & & & \\
S1 & 436,40 & 416,40 & 26,85 & 31,50 & 911,15 & 921,00 & 98,93 \\
S2 & 1313,60 & 676,00 & 275,50 & 293,20 & 2558,30 & 2604,00 & 98,25 \\
S3 & 218,88 & 0,00 & 68,65 & 291,20 & 578,73 & 545,00 & 106,19 \\
& & & & & 19412,9 & & \\
S4 & 17000,00 & 2080,00 & 0,00 & 332,90 & 0 & 18555,00 & 104,62 \\
S5 & 90,00 & 42,80 & 0,00 & 81,20 & 214,00 & 233,00 & 91,85 \\
S6 & 303,30 & 90,13 & 0,00 & 90,00 & 483,43 & 507,00 & 95,35 \\
S7 & 1838,00 & 131,00 & 92,40 & 186,30 & 2247,70 & 2342,00 & 95,97 \\
S8 & 3067,20 & 1526,40 & 0,00 & 400,80 & 4994,40 & 5125,00 & 97,45 \\
S9 & 30,72 & 128,00 & 34,15 & 93,00 & 285,87 & 276,00 & 103,58 \\
& & & & & & & \\
& & & & 1883,2 & & & \\
BS & 2883,20 & 17,88 & 10,65 & 0 & 4794,93 & 5100,55 & 94,01 \\
\hline
\end{tabular}

The $\mathrm{Pb}$ concentrations associated with the oxidizable fraction (F3) ranged from 1,77-3,86\% in mining residues samples and from $0.00-17,86 \%$ in soil samples. F3 was the fraction with the lowest $\mathrm{Pb}$ content in the majority of the collected soil samples. The $\mathrm{Zn}$ content in $\mathrm{F} 3$ were ranged from $3,62-4,83 \%$ in mining residues samples and from $0.00-11,95 \%$ in soil samples. The oxidizable fraction (F3) is associated with the organic and sulfide fraction. In this study, taking into account the values obtained for the organic matter content, it seems reasonable to assume that most of the oxidizable zinc and lead were mainly associated with organic matter. Nevertheless, this fraction was too low for both $\mathrm{Pb}$ and $\mathrm{Zn}$. This fact may be related to the 
findings reported when the BCR procedure was developed [3], indicating that organically bound metals are extracted to some extent in the second step of the sequential extraction method. Besides, several authors have reported that oxidation of organic matter by acidified hydrogen peroxide is incomplete and the primary sulfide minerals, including $\mathrm{PbS}$ (galena), sphalerite $(\mathrm{ZnS})$, pyrite $(\mathrm{FeS} 2)$ and marcasite $(\mathrm{FeS} 2)$, cannot be totally dissolved by this step $[16,17]$.

Table 5. Fractionation of $\mathrm{Pb}$ by BCR sequential extraction (concentration in $\mathrm{mg}^{\mathrm{kg}}{ }^{\mathrm{l}}$ ), for soil and mining residues in the vicinity of the abandoned Sidi Bou Othmane mine.

\begin{tabular}{cccccccc}
\hline & $\begin{array}{c}\text { Exchangeable } \\
\text { (F1) }\end{array}$ & $\begin{array}{c}\text { Reducible } \\
\text { (F2) }\end{array}$ & $\begin{array}{c}\text { Oxidizable } \\
\text { (F3) }\end{array}$ & $\begin{array}{c}\text { Residual } \\
\text { (F4) }\end{array}$ & Sum & $\begin{array}{c}\text { Total } \\
\text { concentration }\end{array}$ & $\begin{array}{c}\text { Recovere } \\
\text { d \% }\end{array}$ \\
\hline RM1 & 2862,56 & 4809,36 & 185,05 & 51,34 & 8808,31 & 9240,00 & 95,33 \\
& & & & & 15399,9 & & \\
RM2 & 5771,79 & 8857,02 & 526,00 & 245,12 & 3 & 16811,43 & 91,60 \\
RM3 & 2806,65 & 4702,83 & 152,23 & 41,77 & 8603,47 & 9250,00 & 93,01 \\
& & & & & 18763,3 & & \\
RM4 & 6268,26 & 10404,80 & 725,00 & 365,25 & 1 & 20628,57 & 90,96 \\
& & & & & & & \\
S1 & 20,60 & 242,40 & 6,12 & 64,00 & 333,12 & 320,00 & 104,10 \\
S2 & 144,36 & 1178,40 & 121,00 & 257,60 & 1701,36 & 1678,00 & 101,39 \\
S3 & 44,00 & 70,00 & 30,00 & 24,00 & 168,00 & 159,00 & 105,66 \\
S4 & 2216,80 & 800,00 & 0,00 & 428,10 & 3444,90 & 3323,00 & 103,67 \\
S5 & 30,12 & 88,21 & 10,00 & 35,00 & 163,33 & 174,00 & 93,87 \\
S6 & 100,00 & 202,00 & 6,00 & 17,24 & 345,24 & 329,00 & 104,94 \\
S7 & 800,00 & 5156,80 & 0,00 & 252,10 & 6208,90 & 5922,00 & 104,84 \\
S8 & 1445,00 & 2488,00 & 500,00 & 150,00 & 4583,00 & 4634,00 & 98,90 \\
S9 & 15,00 & 63,00 & 20,00 & 20,00 & 118,00 & 125,00 & 94,40 \\
& & & & & & & \\
BS & 2883,20 & 17,88 & 10,65 & 1883,20 & 4794,93 & 5100,55 & 94,01 \\
\hline
\end{tabular}

The $\mathrm{Pb}$ concentration associated with the residual fraction (F4) ranged from $0,58-1,95 \%$ ) in mining residues and from $0.00-21,43 \%$ for soil samples. As regards to Zinc, the concentrations obtained ranged from 1,06-1,36\%) in mining residues and from 1,71-50,82\% for soil samples.

The residual solid should mainly contain primary and secondary minerals, which may hold trace metals within their crystal structure. Therefore, it does not seem reasonable to assume that these metals may be released under the conditions normally encountered in nature.

\section{CONCLUSIONS}


Environmental pollution by heavy metals originated from abandoned mines can become a very important source of contamination both in soil and water. Therefore, the characterization of mining tailings' chemical and physical properties is important to assess the risk of potential environmental mobility of toxic trace metals that are contained in this kind of waste.

The chemical characteristics of mining residues and soils in the vicinity of the zinc-lead abandoned mine of Sidi Bou Othmane showed that in general, all samples presented a neutral to alkaline $\mathrm{pH}$ similar to background samples, the alkaline $\mathrm{pH}$ could be attributed to the presence of carbonates with a high concentration, the characterization revealed that, the electrical conductivity presents more variability than the $\mathrm{pH}$. All the soil samples presented a very high Organic matter content similar to background samples, these values are due to the nature of this soil (Arable land and cultivated soils ), the presence of a vegetation cover in some parts of the mining area, and the mixture of the mining residues with a soil, could explain the high values of organic matter content in samples corresponding to the mining residues, Likewise, the influence of organic matter content, $\mathrm{pH}$, carbonate levels, and interactions among these factors appeared to be central in the distribution of the heavy metals among the different geochemical phases of the soils.

The total heavy metal concentrations showed that the highest concentrations were $\mathrm{Zn}$, and $\mathrm{Pb}$, except for S5 and S9, all the total concentrations were up the Maximum allowable concentrations of heavy metals for agricultural soils from European Directive 86/278/EEC.

The results obtained after the application of the sequential extraction recommended by the BCR indicated that $\mathrm{Pb}$ was mainly associated with the reducible fraction (F2) in all the collected samples. Zn was mainly associated with the F1 fraction (exchangeable, water- and acid-soluble) in soil and associated with the F1 fraction and oxidizable fraction ( F3) in mining residues, thus being more mobile and potentially more dangerous for the environment of the studied area. It would be necessary to remove or stabilize the mine waste, since, nowadays; it is a source of soil pollution as the tailings continue to release heavy metals into the environment the heavy metal pollution of the surrounding arable lands for example.

\section{ACKNOWLEDGMENTS}

The present work has been carried with support of the Pole of competences on Water and Environment (PC2E-Morocco), the Morocco-Spanish project NA/011433/07 "Estudio de la Movilidad de metales pesados en suelos contaminados" and SOWAEUMED project, coordination action, FP7-REGPOT-2009-2.

\section{REFERENCES}

[1] Adriano, D.C., 1986. Trace elements in the terrestrial environment. Springer-Verlag, New York.

[2] Alonso Alvarez, E., Callejon M., Jimenez, JC., Ternero M., 2002. Heavy metal extractable forms in sludge from wastewater treatment plants. Chemosphere 47:765-775.

[3] Sahuquillo A, Lopez-Sanchez JF, Rubio R, Rauret G, Thomas RP, Davidson CM, Ure AU., 1999. Use of a certifired reference material for extractable trace metals to assess sources of uncertainty in the BCR three-stage sequential extraction procedure. Anal Chim Acta 382:317-327.

[4] Pickering, W.F., 1986. Metal ion speciation - soils and sediments (a review). Ore Geol. Rev. 1, 83-146. 
[5] Murray, K., Cauvet, D., Lybeer, M., Thomas, J.C., 1999. Particle size and chemical control of heavy metals in bed sediment from the Rouge River, southeast Michigan. Environ. Sci. Technol. 33, 987-992.

[6] The Cuong, D., Obbard, J.P., 2006. Metal speciation in coastal marine sediments from Singapore using a modified BCR-sequential extraction procedure. Appl. Geochem. 21, 13351346.

[7] G. Aubert, Méthodes d'analyses des sols. G.R.D.P., Marseille, 1978, 80-83,123-127.

[8] özge, H., Halil, H., Nilu"fer NK.,Sibel A., 2008.Evaluation for Agricultural Usage with Speciation of Heavy Metals in a Municipal Sewage Sludge. Bull Environ Contam Toxicol $.81: 42-46$.

[9] El Hachimi, M.L., El Founti, L., Bouabdli, A., Saidi, N., Fekhoui, M., Tasse,N.,2007. Pb and As in mining alkaline waters: contamination, comportment and risks (the Zeida abandoned mine, Morocco), Rev. Sci. Eau 20 .1-13.

[10] Plassard, F., Winiarski,T., Petit-Ramel, M.,2000. Retention and distribution of three heavy metals in a carbonated soil: comparison between batch and unsaturated column studies, J. Contam. Hydrol. 42 99-111.

[11] Kabata-Pendias, A., Pendias, H., 2000. Trace Elements in Soils and Plants. CRC Press, Boca Raton, 287 pp

[12] Council of the European Communities, 1986. Directive (86/278/EEC) on the protection of the environment, and in particular of the soil, when sewage sludge is used in agriculture. Off. J. Eur. Communities L181, 6-12 [04/07/86].

[13] Wilson, B., Pyatt, F.B., 2007. Heavy metal dispersion, persistence, and bioaccumulation around an ancient copper mine situated in Anglesey, UK. Ecotox. Environ. Safe 66, 224-231. [14] McLean, J.E., Bledsoe, B.E., 1992. Behaviour of metals in soils. USEPA Ground Water Issue. EPA/540/S-92/018.

[15] Lee, S., 2006. Geochemistry and partitioning of trace metals in paddy soils affected by metal mine tailings in Korea. Geoderma 135, 26-37.

[16] Li, X., Thornton, I., 2001. Chemical partitioning of trace and major elements in soils contaminated by mining and smelting activities. Appl. Geochem. 16,1693-1706.

[17] Cappuyns, V., Swennen, R., Niclaes, M., 2007. Application of the BCR sequential extraction scheme to dredged pond sediments contaminated by $\mathrm{Pb}-\mathrm{Zn}$ mining: a combined geochemical and mineralogical approach. J. Geochem. Explor. 93, 78-90. 